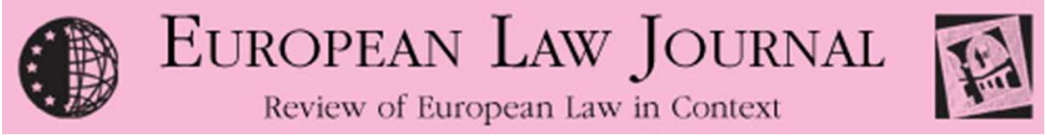

\title{
Forward or Back: The Future of European Integration and the Impossibility of the Status Quo
}

\begin{tabular}{|r|l|}
\hline Journal: & European Law Journal \\
\hline Manuscript ID & ELJ-Dec-2015-0162.R1 \\
\hline Manuscript Type: & Original Manuscript \\
\hline Keywords: & EU, Integration, Governance, European Court, Legitamacy \\
\hline \multicolumn{2}{|l}{} \\
\hline
\end{tabular}

SCHOLARONE ${ }^{m}$

Manuscripts 


\title{
Forward or Back: The Future of European Integration and the Impossibility of the Status Quo
}

\begin{abstract}
This article considers how the legal and political order of the European Union can cope if the 'Ever Closer Union' envisaged by the Treaties ceases to be inevitable. In particular, it focuses on what are the likely consequences if previously successful integration mechanisms such as integration through law (including adventurous pro-integration interpretation by the CJEU) and functional integration, can no longer successfully push forward the integration process. It considers whether it is possible for the Union to 'stand still', that is, to maintain the current level of integration without either moving forward to more intensive integration or engaging in costly and disruptive disintegration. In order to substantiate this claim, the article looks at three areas, the law of citizenship, the Eurozone and the legislative structures of the Union, showing in each case that the neither the current degree of integration nor methods used in recent times to move the integration process forward, provide a long term basis for policy.
\end{abstract}

\section{Introduction}

The topical example of the UK aside, there appears to be little political will in EU states to leave the Union or to reverse the process of European integration. At the same time, there is also a lack of political will for intensive further integration. Could keeping things as they are be a possible solution for the European Union? This article suggests that it could not. There is very limited political appetite for significant further transfers of political and economic powers to the EU. At the same time there is equally, limited support for reversing European integration, for example, by leaving the Euro or abolishing free movement rights. This desire to maintain the status quo would not be a problem if maintaining currently levels of integration were feasible. However, this article argues that this is not the case. The European Union operates on the basis that its current legal and institutional arrangements are temporary and will be replaced by more integrated versions in the future. Because the current set-up is not designed to be permanent, current structures and levels of integration will tend produce policy incoherence ${ }^{1}$

\footnotetext{
${ }^{1}$ For the purposes of this article I define "policy incoherence" as a situation where different EU rules or a combination of EU and national rules, operate at cross purposes, undermining the ability of each to achieve the
} 
and unsustainable inflexibility if maintained largely as they are. The Union may therefore struggle to cope if, as some Member States desire, it is decided to maintain current levels of integration indefinitely rather than moving progressively towards ever closer union.

The term "integration" has a range of meanings and the Union over the course of its history has adopted various methods of integration from outright legal harmonisation and extinguishing of the individual competence of Member States in an area, to informal cooperation and coordination mechanisms. For the purposes of this article, I use the term "integration" or "more integration" as referring to a process through which more authority is granted to EU institutions either in the form of the transfer of competence over new areas of policy or by adaptation of decision-making rules so that the means by which decisions in relation to such policy areas are made becomes more supranational with increased capability for Union bodies to make or adapt law and policy without the agreement of all Member States. Central cases of this kind of integration would be instances of the extension of Union competence to new areas (for example by establishing and conferring powers over monetary policy on the European Central Bank), the adaptation of voting rules so that the Union could pass laws on a matter with a qualified majority in the Council rather than by unanimity (as occurred in a wide range of areas in the Lisbon Treaty) or the extension of the rights conferred on individuals or bodies by EU law (as occurred with the passage of legislation expanding the right of EU citizens in the Citizenship Directive ${ }^{2}$ or through Court rulings such as Cassis de Dijon ${ }^{3}$ which expanded the right of businesses to benefit from mutual recognition of regulatory decisions by Member States). It could also cover conferral of a co-ordinating or reviewing role for EU institutions where none had previously existed though this form is categorised as 'less intense' than other forms.

In order to substantiate its claim, the article looks at three areas, the law of citizenship, the Eurozone and the legislative structures of the Union, showing in each case that the current degree of integration cannot provide a long-term basis for policy. The first section sets out a

\footnotetext{
goals intended or where the rules and structures brought about by the degree of integration achieved to date produce otherwise avoidable negative outcomes for the Union and its Member States.

${ }^{2}$ Directive 2004/38/EC of the European Parliament and of the Council of 29 April 2004 on the rights of citizens of the Union and their family members to move and reside freely within the territory of the Member States OJ L 22929.6.2004 p.35-48.

${ }^{3}$ ReweZentral AG. (120/78) [1979] E.C.R. 649.
} 
brief history of integration and the role of the law and EU judiciary in promoting it. It provides some reasons why previously successful integration methods may not be as successful as before in the future. Section two looks at the recent rulings of the Court of Justice on citizenship rights and social welfare entitlements in cases such as Dano ${ }^{4}$ and Aliamovic ${ }^{5}$ to demonstrate the problems that result when the court feels unable to continue to develop a concept such as Union citizenship in a way that continues the expansion of the rights held by EU citizens. This section shows how key legal concepts such as EU citizenship and the rights that attach to them have been designed on the basis that they would progressively develop in a more integrationist direction (i.e. they would come to encompass more and more rights over time). This means that attempting to maintain existing EU citizenship rights as they are (rather than continually developing them in an integrationist direction), produces severe confusion and incoherence in policy. Section three shows how the problems highlighted in Dano are not restricted to citizenship issues but are reflective of wider problems faced by the Union, most notably in relation to the design of the Eurozone and the structure of the Union's law-making structures themselves which is dealt with in section four.

\section{Section I: Key Issues and the Impossibility of Partial Integration}

\section{-The Two Costs of Standing Still: Incoherence and Rigidity}

Ever closer union has been a key rhetorical plank of European treaties from the very beginning of the integration process and integration in the decades since has usually involved increasing the range of competences of the EU and extending the ability of EU institutions to enact policies within these areas of competence independently of Member States (for example, by allowing the adoption of laws by a qualified majority vote ('QMV') 'in the Council of Ministers instead of requiring unanimity). In recent years, particularly since the outbreak of the financial crisis, other methods of integration that give less power to supranational Union institutions and which stress intergovernmental action and mutual monitoring amongst Member States, have been attempted. A key contention of this article is that this form of integration is unlikely to allow for the effective functioning of the European Union. In some key instances, only the kinds

\footnotetext{
${ }^{4}$ Dano (C-333/13) EU:C:2014:2358, 11 November, 2014.

${ }^{5}$ Alimanovic (C-76/14) EU:C:2015:597, 15 September 2015.
} 
of integration that are politically unpalatable such as expansion in the rights granted by EU citizenship or increasing the supranational powers of EU institutions in areas such as economic policy can address the policy problems faced by the Union and its Member States. ${ }^{6}$ Neither the newer forms of integration attempted nor 'standing still' i.e. simply maintaining current levels of integration, are not sustainable options because current EU legal principles and decisionmaking structures are based on the assumption that they are merely transitional arrangements that apply pending the realisation of a more supranational and less intergovernmental future.

This is problematic as several Member States and much of the European electorate, even if broadly content with current levels of integration, are not keen on the idea of an ever intensifying increase in integration and in the powers of the Union. 'Standing still' and maintaining existing EU legal rights and levels of integration without moving progressively to more intense integration is not a viable solution. The current distribution of competences between Union and Member States, produces incoherence in policy and excessive rigidity in many areas. By 'incoherence' I mean that this distribution of competences brings about a situation where different EU rules operate at cross purposes, undermining the ability of each to achieve the goals intended or where the rules and structures brought about by the degree of integration achieved to date produce otherwise avoidable negative outcomes for the Union and its Member States.

A degree of incoherence or ineffectiveness is fairly common in a number of polities. What makes the kind of incoherence and ineffectiveness experienced by the Union more grave is that, current arrangements preclude the Union from resolving such incoherence in effective ways. Edmund Burke noted that 'A State without the means of some change is without the means of its conservation'. ${ }^{7}$ At current levels of integration, decision-making structures in the Union are exceptionally rigid and do not provide the necessary means of change in law and policy. In order to protect Member State autonomy, they provide so many opportunities to prevent change in EU law that they risk preventing the EU legislature from adapting the law in the very large range of areas that the Union already regulates. New forms of integration,

\footnotetext{
${ }^{6}$ I will refer to this integration in this way as 'intensifying integration' for simplicity's sake.

${ }^{7}$ E Burke, Reflections on the Revolution in France (Oxford World Classics, 1993) (L G Mitchell ed.).
} 
notably in relation to the Eurozone have not succeeded in providing the necessary flexibility and may not be applicable to other areas of EU activity. This means that areas such as EU employment law and EU environmental policy, where changing information and changing economic circumstances mean such adaptation can be vital continue to be subject to excessively rigid decision-making structures. In summary, current levels of integration can function so as to produce the need for further unattainable integration and that unmet need can be damaging. The elements of the status quo are actively damaging may not be changeable under current structures. Indeed, even simple adjustment of EU laws that aim only to adapt such laws to changing circumstances and which involve no additional integration may be unattainable under current structures. This must raise significant doubts as to whether current institutional structures can be maintained even if Member States desired to do so.

\section{-The Transitional Nature of Current Structures and the Interpretation of EU Law: Interpreting for the Future}

The idea that current institutional and legal arrangements in the EU are merely transitional stages en route to a more integrated future is seen in what is one of the most distinctive features of EU constitutional jurisprudence; its relationship to time. The European Court's jurisprudence has always had a peculiar relationship to time. When constitutional courts in states are required to make rulings on fundamental questions about the structure of the political system or other constitutional norms, they usually approach the relevant legal texts on the basis that those texts reflect (or constitute) what kind of a polity the relevant polity already is, rather than what it aims to become. A constitution will usually be seen as declaring that a state is a parliamentary democracy not that it is destined to become one. ${ }^{8}$

Often this 'is' draws on the past in that courts look back to the meaning of as they look to what kind of system was established by a particular constitutional provision. Even in interpreting broad constitutional norms such as the meaning of 'liberty' courts often look to the past. Originalists in US constitutional interpretation are concerned to identify what the US

\footnotetext{
${ }^{8}$ See for example the decision of the Irish Court of Appeal the striking down legislation giving wide discretion to the executive to prohibit various drugs on the grounds that it usurped the legislative power of the parliament (Bederev v Ireland [2015] IECA 38).
} 
constitution was and what the norms of the US were at the time of the enactment of the relevant constitution. Even those who are not originalists and see constitutional norms as living or evolving, give weight to legal and political traditions in interpreting the Constitution. For example, in deciding what is encompassed by the 'substantive due process' clause of the $14^{\text {th }}$ Amendment, the US Supreme Court devotes significant attention to the question of whether the liberty in question can be seen as deeply rooted in the traditions of the US. Constitution. ${ }^{9}$ The invocation of a 'block of constitutionality' by the French Constitutional Council also draws on principles and traditions from the Republic's past (such as the Declaration of the Rights of Man) to develop a vision of France's constitutional present. ${ }^{10}$

Even where there is no codified constitutional document as in the UK, rulings on key questions such the admissibility of evidence tainted by torture, cited the tradition of the common law as contributing to the current reality of the legal system. ${ }^{11}$ There is often an element of aspiration in this invocation of the 'is' and 'was' in that particular traditions or current realities may be regarded as helping to achieve a better future, but this future orientation is less important than identifying traditions from the legal past that contribute to the present.

The European constitutional system is different in this regard. Mancini suggested that the Treaties had a pro-integration 'genetic code' which encouraged, or possibly required, the Court to interpret EU law in a pro-integration manner. ${ }^{12}$ The preamble to the Treaty spoke of '[laying] the foundations of ever closer union ${ }^{13}$ between the peoples of Europe. Thus, the idea that the bodies set up by the treaties were merely foundations of a project that would later be realised

\footnotetext{
${ }^{9}$ See for example, Lawrence $v$ Texas 539 US 558 where Kennedy J for the majority based his decision to overturn laws criminalising gay sex on a claim that anti-sodomy statutes were 'far from possessing 'ancient roots"' (p. 570) that 'in our tradition the state is not omnipresent in the home' (p. 563) and invoking 'the laws and traditions of the past half-century' (p. 571-2). In dissent Scalia J reiterated the Court's repeated statement that rights 'deeply rooted in this Nation's history and tradition' were covered by the $14^{\text {th }}$ Amendment's protection of liberty (p. 593).

${ }^{10}$ e.g. Décision $n^{\circ} 71-4$ DC du 16 juillet 1971, Décision $n^{\circ}$ 77-87 DC du 23 novembre 1977, 'liberté d'enseignement et de conscience', Décision $n^{\circ}$ 99-414 DC du 8 juillet 1999, 'loi d'orientation agricole', Décision $n^{\circ}$ 77-87 DC du 23 novembre 1977, 'liberté d'enseignement et de conscience'.

${ }^{11}$ See for example the statement of Lord Bingham in the House of Lords in A v Secretary of State for the Home Department (No.2) [2005] UKHL 71 that the Common Law had regarded 'torture and its fruits' with abhorrence for over 500 years and noting that this was a 'deeply rooted tradition'.

${ }^{12}$ See F Mancini and D Keeling, 57 Modern Law Review (1994) 175 see also F. Mancini in Democracy and Constitutionalism in the European Union 44.

${ }^{13}$ Treaty Establishing the European Economic Community, Preamble.
} 
to a greater extent was in the Treaties from the very start and remains to this day (indeed its removal was one of the key goals of the British government due to their opposition to further integration).

In this context, it is well-known that the European Court of Justice's interpretation of the EU's foundational constitutional documents has often enhanced the supranational elements of the EU but its approach to interpretation has also been noticeable for the fact that it is highly future-oriented. The Court's teleological approach and commitment to ever closer union has meant that it has interpreted constitutional and legal texts with an eye to what the Union was intended or destined to become, not what it actually is. For example, even back in the late 1970s and early 1980s, the Court gave interpretations of the Treaty provisions relating to the European Parliament that were very protective of the EP's powers. This view was underpinned by a vision of the Parliament as a provider of necessary democratic legitimacy to the lawmaking process in Europe even before MEPs could really be seen as genuine holders of a democratic mandate to speak on behalf of European citizens. ${ }^{14}$ In other words, the Court protected the Parliament on the basis of the role that it will have to play in the future if a more integrated and powerful Union is to be legitimate.

Similarly, as will be discussed in more detail below, the Court has interpreted EU citizenship not in the light of the rather meagre rights that attached to it at its birth ${ }^{15}$ but in the light of what it envisaged that it would become in the future. The central rhetorical plank of the Court's approach to citizenship has been its assertion in the Grzelcyck $^{16}$ case, which it has often repeated (including in Dano), that EU citizenship is 'destined to become the fundamental status' of EU citizens. ${ }^{17}$ Thus, the Court was interpreting the concept of citizenship, not on the basis of what it is, but what it will (or should) become. EU citizenship has been seen by the Court as something that will be subject to transformation by a process of ever closer integration that will transform it into the fundamental status of EU citizens. On this approach, citizenship's

\footnotetext{
${ }^{14}$ See for example Roquette Frères v Council 138/79 [1980] E.C.R. 3333 and Les Verts v Parliament 190/84 [1988] E.C.R. 1017.

${ }^{15}$ S. O'Leary The Evolving Concept of Community Citizenship (Kluwer, 1996).

${ }^{16}$ Grzelcyck C-184/99 [2001] E.C.R. I-6193.

${ }^{17}$ Above at [31].
} 
current, more limited reality, would be interpreted in this light and would be therefore be expansively interpreted in order to be capable of fulfilling this larger future role.

This orientation towards the future was perhaps inevitable given the commitment in the Treaties to 'ever closer union' which is an inherently future-oriented concept in that it refers to the future of the integration process. The fact that the Court has interpreted particular concepts not for what they are but for what they hope them to become, should not therefore surprise us. It should be noted that the treaties speak of ever closer between the 'peoples' of Europe. The use of the plural in this context, as well as the later inclusion of commitments to subsidiarity and to respecting the diversity of Member States show that the integration process was always intended to have limits and would never reach the point where Member States were entirely replaced by the Union. Nevertheless, the facts that the Treaties did not envisage the extinction or replacement of Member States and that the European Council was willing to acknowledge (in the pre-referendum deal offered to the UK) ${ }^{18}$ that all states were not committed to closer political union, do not mean that over the past five decades the 'direction of travel' of the integration process (i.e. 'closer union') has not been clear. Treaty changes since the 1990s did include principles such as subsidiarity which could be seen as favouring national rather than EU level action and allowed various member states (most notably the UK) to opt out of the integration of various policy areas, however this has not changed the fact that the clear overall trend has been to increase the supranational nature of the Union and to widen its competences.

Despite periods of stagnation and occasions, such as the Luxembourg crisis of 1965, where the primacy of national interests and a desire to ensure that states could block actions perceived to threaten their interests have brought the integration process to a halt, the predominant trend in the European integration process has been towards more intensive integration. At least until the outbreak of the Eurozone crisis, each treaty change had involved extension in the

\footnotetext{
${ }^{18}$ European Council, Draft Decision of the Heads of State or Government, meeting within the European Council, concerning a New Settlement for the United Kingdom within the European Union 4/16 2 February 2016.
} 
competences of the Union and the expansion in the use of voting procedures, such as Qualified Majority Voting in the Council, that enhance the supranational nature of the EU. Unlike many federal states where there the boundaries of federal power are largely fixed in a grand bargain between the states and the centre the EU has seen near constant change in the boundaries of its competence with frequent competence-expanding treaty changes over the past 25 years. The degree to which the Union's powers are intended to evolve was further underlined by the adoption of the 'passarelle' clause ${ }^{19}$ in the Lisbon Treaty which envisages changing power balances between the Union and Member States by unanimous agreement between Member States without the need for Treaty change. Increasing political resistance to integration has certainly had some effect. Treaty references to the diversity of Member States and commitments to substidiarity have been introduced and, as part of the failed bid to encourage the voters of the United Kingdom to remain in the Union, Member State governments offered a new, less integrationist interpretation of the term "ever closer union." ${ }^{20}$ However, none of this changes the reality that the version of ever closer union seen in Treaty revisions has consistently been to expand the range of competences of the Union and to steadily enhancement of over the past three decades, the powers and institutional structures of increase the supranational nature of EU decision making. Ever closer union in practice has

\footnotetext{
${ }^{19}$ Treaty on European Union, Article 48, OJ C 326, 26.10.2012.

${ }^{20}$ References in the Treaties and their preambles to the process of creating an ever closer union among the peoples of Europe are primarily intended to signal that the Union's aim is to promote trust and understanding among peoples living in open and democratic societies sharing a common heritage of universal values. They are not an equivalent to the objective of political integration.
}

Therefore, the references to an ever closer union among the peoples of Europe do not offer a basis for extending the scope of any provision of the Treaties or of EU secondary legislation. They should not be used either to support an extensive interpretation of the competences of the Union or of the powers of its institutions as set out in the Treaties.

European Council, Draft Decision of the Heads of State or Government, meeting within the European Council, concerning a New Settlement for the United Kingdom within the European Union 4/16 2 February 2016 
meant that the powers and institutional set up of the Union have not been regarded as definitive but rather as a temporary set ups on the road to the next phase of integration. ${ }^{21}$

\section{Ever Closer Union, Functional Integration and Integration through Law: Means to a More Integrated Future}

The constant evolution in EU competences and institutions is not surprising. The idea that EU structures were not intended to be permanent but rather provisional precursors to a more integrated future was deeply woven not just into the language of the Treaty but also the method of integration chosen by those who founded the EEC, that of functional integration. As Wallace notes, Jean Monnet was both a federalist and also committed to a strategy of 'elite-led gradualism. ${ }^{22}$ Under this strategy, integration of functional areas would bring benefits that would generate populate support for more integration or as Holland states: '[Monnet] saw the emergence of loyalties to Community institutions developing as a consequence of elite agreements for the functional organization of Europe. ${ }^{23}$

Although they were open about the fact that they were launching a politically ambitious project that was intended to develop over time, those who launched the project of European integration chose a process of integration that involved avoiding politically and symbolically charged areas such as defence and foreign policy whose integration had provoked major political resistance. ${ }^{24}$ They focused instead on integrating less controversial 'functional' areas. Their hope was that integration would then proceed by means of 'spill-over' i.e. that integration of one area would create the momentum for integration in another. Scholars such as Lindberg have long noted the nature of this functional integration to be somewhat self-sustaining. He defined 'spill-over' as 'a situation in which a given action, related to a specific goal, creates a

\footnotetext{
${ }^{21}$ This may partly explain why the ECJ has so rarely played the role that constitutional courts often play in other multilevel polities: the role of policing the limits of federal authority. National constitutional courts usually interpret constitutions that establish fixed the boundaries of competence between the central government and the sub-national units. As the boundary between the Union's competence and that of the Member States was, under the text of the Treaty, expected to continually shift in favour of the Union, it is not surprising that the ECJ has only rarely intervened to enforce boundaries on EU competence.

${ }^{22} \mathrm{H}$ Wallace 'European Governance in Turbulent Times' 199331 JCMS 293.

${ }^{23}$ M Holland European Community Integration (Saint Martins Press 1993), 16 quoted in P Craig in P Craig and G. De Burca (eds.) The Evolution of EU Law Oxford and New York, Oxford University Press, 1999$) 6$.

${ }^{24}$ An attempt to found a European Political Community in the 1950s had been rejected by the French Parliament.
} 
situation in which the original goal can be assured only by taking further actions, which in turn create a further condition and a need for more action and so forth ${ }^{25}$.

It is notable that the choice made was of a mechanism that avoided integrating politically controversial or symbolically important areas. However, it was also recognised that such avoidance could not be permanent. The approach of the founders of the Union is reminiscent of Saint Augustine's famous request "Lord make me chaste, but not yet". They chose the mechanism of functional integration in the hope that it would be economically successful and would establish a degree of interdependence that would progressively make integration of such controversial areas necessary and more palatable to electorates over time. In other words, the positive impact of integration would bring about support for further integration. Thus, we see that, from the beginning, an approach was being sought that could compensate for the initial weakness of popular support for intensive integration (and possibly remedy it by provoking, as will be discussed below, the growth of European identity). Craig notes that this neofunctionalist view was the dominant ideology of Community integration. It was, he argues 'intuitively attractive' but also suffered from being 'economically deterministic'. It failed to explain the actual course of integration which did not proceed in a smooth linear fashion. Rather than progressing smoothly, the integration process moved in fits and starts and experienced repeated episodes, such as the Luxembourg crisis of 1965 where assertions of national interest caused the process to stall. This led to qualification of neo-functionalist theories in later later explanations such as the intergovernmental approach of Moravscik. ${ }^{26}$

Nevertheless, neo-functionalism was not discredited and has, in qualified form, retained significant force as an explanation of elements of the integration process. Craig notes that:

'The neofunctionalist account had dismissed the normative importance of democratic institutions, on the ground that the increased affluence rendered possible by technocracy

\footnotetext{
${ }^{25}$ L N Lindbergh The Political Dynamics of European Economic Integration (Stanford, Stanford University Press, 1963 ) at p. 10 quoted in B Rosamond Theories of European Integration (Macmillan Press, Hampshire and London, 2000) at p. 60.

${ }^{26}$ A Moravcsik Preferences and Power in the European Community: An Intergovernmentalist Approach'1993 Journal of Common Market Studies 31473.
} 
would produce the consensus of apathy which undermined any active interest in or concern for the political process. ${ }^{27}$

However he concludes that, although it is always difficult to show causality in these matters 'it is arguable that functional spill-over created and continues to create come impetus for further integration.' ${ }^{28}$ This view has much to recommend it. Although neo-functionalism had underestimated the influence of factors beyond the hoped for economic benefits of integration and although it had not predicted the stop and start nature of the progression of the integration process, it was central to the vision of founders such as Monnet and, notwithstanding various incidents of stagnation or stalling in the integration process, the overall trend of the integration has been for integration in one area to create a need for integration in another and a constant (though not smooth) movement in the direction of further integration.

The fact that this consistent trend towards further integration continued was, to a significant degree, made possible by the role of law in the integration process. As neo-functional integration was not based on mass support it was vulnerable to eruptions of nationalist feeling or when integration touched on any controversial issues. The high degree of political consensus amongst member states in relation to social and economic policy in the post-war period reduced the risk that European integration would become a means by which highly controversial policy agendas were advanced. Such consensus has been declining since the 1970 s and has been badly fractured by the current economic crisis. Of course, this is not to say that the question of European integration was not, even in the early decades of the Community, the subject of vigorous political dispute or that voters and politicians were unaware in the early days of the Community that the integration process being launched was highly ambitious and likely, eventually, to touch on highly salient political matters. However, knowledge that, in the future a highly salient political issue such as national defence or budgetary policy may come under a future European polity produces very different political

\footnotetext{
${ }^{27}$ P Craig in P Craig and G. De Burca (eds.) The Evolution of EU Law Oxford and New York, Oxford University Press, 1999) 7.

${ }^{28}$ Ibid. 5.
} 
reactions from those produced by attempts to extend in the present, European competence to such matters. Thus, the possibility that the Euro may one day requires a common EU finance ministry is a lot less alarming to electorates and produces much less intense political backlash than a proposal to establish such a ministry today. The early days of the Community were not entirely politically harmonious and vigorous political disputes on matters such as the Common Agricultural Policy, ${ }^{29}$ the role of national vetoes ${ }^{30}$ and the question of the financing of the Community. ${ }^{31}$ However, though these matters were hotly-contested at the time, they were of considerably less political (and electoral) salience than matters such as control of budget deficits and immigration policy which constitute the terrain on which disputes around the boundaries of EU competence are fought out today.

Because disputes in relation to EU policies and powers did not relate to issues that were matters that were of the utmost salience to electorates and because Western Europe enjoyed relatively high levels of political consensus on socio-economic policy in the early decades of the integration process, there was significant scope for judicial institutions to play a role in unblocking political deadlock without provoking an uncontrollable political backlash. Provided that the relevant matters were not matters of life and death importance to electorates, the politically-insulated nature of the legal process could allow integration to be carried out in a context somewhat shielded from politics and potentially popular invocations of national interests. Indeed, given the counter-majoritarian tendencies of constitutional adjudication (particularly in the context of the EU treaties where a tiny minority (i.e. a single state) could block constitutional change), it is unsurprising that law, and constitutional jurisprudence, were key methods through which integration insulated from political controversy could be achieved. Scholars have long noted the key role played by law and by judicial interpretation in the process of European integration. Weiler, Ceppelletti and Seccombe noted centrality of law to the development of what was then the European Community in their seminal 1986 study of 'Integration through Law' in which they stated 'the law is both the object and the agent or

\footnotetext{
${ }^{29}$ See the account of the Stresa Conference of 1964 in European Commission, The European Commission 1958-72: History and Memories, (European Commission, 2007).

${ }^{30}$ For example the 'empty chair crisis' of 1965-66.

${ }^{31}$ For example the debate around the 'own resources question' in 1970.
} 
instrument of integration. While law is a product of the polity, the polity is also to some extent the creature of the law. ${ }^{32}$ They were correct. European law, both in the form of the Treaty and secondary legislation adopted by European institutions, has been central to moving the integration project forward. This integration has often taken the form of EU legislation or ECJ decisions expanding the scope of EU rights but it has also taken other forms such as informal cooperation and coordination of policies, soft law instruments such as issuing "Guidelines" and, particularly since the outbreak of the Eurozone crisis, various forms of monitoring and reporting (discussed in more detail below). Despite the increasing importance of such integration mechanisms, integration by means of enacting legislation or by pro-integration interpretations of EU treaties and legislation by the Court of Justice have been significant drivers of the integration process. Although political debate remains resolutely national and the EU budget remains tiny compared to national budgets, the Union has passed a vast amount of legislation, even allowing it some scope to regulate, in some circumstances, big spending areas such as health, education and social welfare which remain national competences. In addition, EU law has come to be accepted as a part of national law enforced by national courts. The interpretative approach of the Court of Justice has been key to this process of integration through law.

The Court's interpretation of the Treaties as including the direct effect and primacy of European law had, as many have noted, a transformative effect on the integration process. ${ }^{33}$ Alter showed how, in the past, the Court has been particularly important in breaking political logjams and has pushed integration forward most intensely when political deadlock stalled the integration process. She also has shown how the ECJ has historically been a notably strategically-minded and political court in the sense that it has used its power to decide cases brought before it in a strategic way in order to promote the legal and political integration of the

\footnotetext{
${ }^{32}$ As quoted in D Augenstein 'Identifying the European Union: Legal Integration and the European Communities' in D Augenstein (ed.) 'Integration through Law' Revisited: The Making of the European Polity (Ashgate, Farnham, UK, 2012) 111.

${ }^{33}$ P Craig and G de Burca EU Law: Text, Cases and Materials (3rd ed.) (Oxford University Press, Oxford and New York, 2003) 182.
} 
Union. ${ }^{34}$ For example, famous decisions such as that in Cassis de Dijon ${ }^{35}$ had an impact way beyond the specific issue of free movement of goods and the circumstances under which states should recognise each other's regulatory decisions but were also about using EU law to push forward legal, and therefore political, integration between Member States. Indeed the ruling in Cassis de Dijon provides a good example of both integration through judicial interpretation and of the operation of the 'spill-over' mechanism. The ruling achieved, by means of creative judicial interpretation, a result that had been politically unattainable. ${ }^{36}$ In addition, the ruling promoted a spill-over process. The Court's ruling that Treaty provisions in relation to free movement of goods included a principle of 'mutual recognition' placed a question mark over the status of large amounts of national regulations and thus changed the political incentives of Member States, making it easier to win their agreement to the enactment of European product standards.

The central role of law in European integration has meant the juridification of public life has been particularly strong in the EU. Large areas of public policy such as competition law, became matters of legal rather than political contestation though as Veitch noted, this phenomenon is not restricted to the EU but has been a notable feature of the globalized economy in general. ${ }^{37}$ In any event, it suffices to say that the law and its interpretation has been a key method through which ever closer union has been achieved to date without the necessity to achieve majority support amongst EU voters

\section{Limits of Integration through Law and Spill-Over: Political Salience}

Just as it was thought that functional integration would bring about popular support for further integration, the process of integration through law was not seen as the end of the integration process. Rather, as Augenstein notes, those who studied and described the phenomenon in the 1980s were of the view that Ilaw as an agent and object of integration triggers a gradual

\footnotetext{
${ }^{34} \mathrm{~K}$ Alter Establishing the Supremacy of European Law: The Making of the International Rule of Law in Europe' (Oxford University Press, 2001). K Alter The European Court's Political Power (Oxford University Press, 2009).

${ }^{35}$ ReweZentral AG. (120/78) [1979] E.C.R. 649.

${ }^{36}$ Although the result of Cassis de Dijon had been unattainable politically, it was not politically salient in the way that budgetary policy or migration policy are today, thus making judicial action to obtain the result a feasible prospect.

${ }^{37}$ S Veitch 'Juridification, Depoliticization and Integration' in Augenstein (ed.) above n. 22 at 93.
} 
process of convergence in the European States that lies at the heart of an emerging European identity'. $^{38}$ In other words, the initial weakness of support for integrating politically or emotionally charged areas of policy could be overcome by the fact of integration of less charged policy areas. Integrating the law in areas would lead to 'a mutually reinforcing process of co-evolution' between law and society. ${ }^{39}$ The overlap with neo-functional analysis is clear. On this view, as Rosamund put it (in relation to the hoped for economic benefits of integration of functional sectors), 'politics would follow economics' ${ }^{40}$ and integration would trigger the sense of European identity necessary for integration of an intensity that was not initially feasible.

This has not proved to be the case. Augenstein rightly notes that an emergence of 'socially differentiated transnational communities' has taken place. However, he suggests that this 'casts doubt on the linkage of convergence with an emerging European identity as it "hardly compares to the more encompassing integration of national societies 'through law' that was envisaged by the Integration through Law school' ${ }^{41}$ We are faced with a situation where the mechanisms of functional integration with spill-over and integration through law, which were intended to resolve the problem of insufficient initial public support for intensive integration, have not produced the sense of shared identity necessary to increase such support. Looking back, the assumption that an 'encompassing integration of societies' would take place seems naïve and deterministic, especially once the Union was expanded from 6 to 28 member states.

Even assuming that the integration process did end up producing economic benefits all-round, it was never a safe bet to assume that politics and loyalty, in Rosamund's words, 'would follow economics'. As Raymond Aron observed 'it is a denial of the experience of [the twentieth] century to suppose that men will sacrifice their passions for their interests' ${ }^{42}$ Though Benedict Anderson was right that they are 'imagined', national identities are very real and remain the fundamental focus for the political loyalty of very many people in Europe. It was perhaps naïve

\footnotetext{
${ }^{38}$ Above $\mathrm{n} 32$.

${ }^{39}$ Bankovwski summarising Augenstein in 'Law, Integration and Progress' in Augenstein (ed.) above $\mathrm{n} 22$ at 115.

${ }^{40} \mathrm{~L} N$ Lindbergh The Political Dynamics of European Economic Integration (Stanford University Press, 1963) at p. 10 quoted in B Rosamond Theories of European Integration (Macmillan Press, 2000) at p. 60.

${ }^{41}$ n. 32 above at 111.

${ }^{42}$ Quoted at p. 114 of T Judt When the Facts Change (Vintage, 2015).
} 
to assume that economic success could effect significant change in this area. Furthermore, as the experience of the misery of intra-European war faded from the memory of most Europeans, awareness of why post-war leaders saw the creation of pan-European institutions as so vital would also fade. Tony Judt wrote of the 'paradox of the welfare state' under which the success of European welfare states would, 'over time, undermined their appeal' as those who grew up under such states would not experience the wrenching poverty or insecurity that motivated those who established welfare systems. Accordingly, they would 'forget why they had sought such security in the first place'. ${ }^{43}$ European integration suffers from an analogous problem. Those who grew up in an integrating Europe do not have experience of anything but peaceful relations between states and the ability to work and travel freely across the continent. They are therefore likely to take such benefits for granted in a way their grandparents would not. Amongst European elites, a degree of European identity did develop. The mass demonstrations against the British exit from the European Union seen in the summer of 2016 did show that, when facing loss of a European identity, many people discovered that it mattered to them rather more than they had realised. On the other hand, the result of the UK's referendum equally showed that such identity is a minority phenomenon and ideas of national sovereignty remain powerfully attractive to many.

Full consideration of the multitude of reasons that such a broader European identity did not grow to the degree as envisaged by the founders of process of European integration is beyond the scope of this article. It may well be that those who launched the integration project fell into what Mark Lilla, in another context, calls 'fantasies of historical inevitability' ${ }^{44}$ and felt that as Bernard Williams said of those who believed in the the inevitability of progress that they were being 'cheered on by the universe'. ${ }^{45}$ After all, in retrospect, there was no reason to think that European identity would inevitably grow as integration proceeded. It may therefore be that the failure of such identity to develop as foreseen is not surprising and that the limited success in creating European identity amongst particular groups was as much as, or more than, could have been expected.

\footnotetext{
${ }^{43}$ Judt , n. 42 above at 324.

${ }^{44}$ M Lilla The Still-Born God (Verso, 2007) at 306.

${ }^{45}$ Quoted in Judt, n. 42 above at 331.
} 
Either way, what is important for my purposes is that the development of European identity and political loyalty to European institutions has not developed to the degree necessary to support intensive further integration between EU member states. At the same time the logic of spill-over (the fact that integration can produce a need for further integration) and Mancini's 'genetic code' of the Treaties that pushes the EU judiciary to interpret them to favour ever closer union, both remain and both encourage a drift towards further integration.

However, this does not mean that these pressures will mean that, notwithstanding a relative lack of support, a continual drift towards further integration will occur. There are reasons to think that the ability of the integration process to proceed with relatively limited public support is coming to an end. Lindberg noted as early as 1966 that integration could cause stress between states when it came to cover more politically salient issues and could thus deter further integration. ${ }^{46}$ The end of the 'permissive consensus' under which public opinion did not significantly oppose transfer of power to European institutions came to an end with the conflict over the ratification of the Maastricht Treaty and has intensified in the decades since. In addition, as integration has deepened, it inevitably begins to touch on more salient issues. Functional integration and the spill-over it generated could never themselves have been used to integrate emotionally-charged or politically salient areas. Rather they were ways to build support for future moves to carry out integration in such areas. Thus, the functional integration and integration through law encourage and require further integration but in the absence of 'loyalty transference' ${ }^{47}$ they may be increasingly incapable of making such integration a reality. As noted above, although there were intense political disputes during the early decades of the Community, at the time, European institutions did not have significant power over the most salient political issues such as welfare policy or budgetary policy and issues over which it had some influence, such as migration, were not the political hot potatoes they are today. This is not the case today where the boundaries of the integration process now lie across the most salient and controversial areas of political life. Once integration efforts begin to affect more politically salient areas such as welfare policy or budgetary policy the political resistance to

\footnotetext{
${ }^{46}$ Rosamond, n. 25 above at 64.

${ }^{47}$ Quoted in Rosamond above, n 25 at. 65-66.
} 
integration becomes too intense for integration through adventurous judicial interpretation or 'elite led gradualism' to be viable options. In addition, unhappy experience of integration be it at a micro level through an event such as the rapid arrival of large numbers of EU migrant workers in a particular town or at a macro level where the unhappy experience of the Euro, may cause increased resistance to future integration. The reality that popular opinion can prevent integration that the spill-over process actively requires can be seen most notably in Jean-Claude Juncker's comment that the Member State governments knew exactly what they needed to do to resolve the Euro crisis but did not know how to get re-elected once they had done this. $^{48}$

\section{Viability of Standing Still: Problem 1: Policy Incoherence}

If there is potentially insuperably strong resistance to further integration in some areas, might the solution be for Member States to maintain current levels of integration without moving further forward? As mentioned above, a key contention of this article is that a system designed for ever-closer union may struggle to function if integration in the sense of expanding the content of EU legal rights or empowering EU institutions and reducing the scope for member states to block the adoption of laws and policies, comes to a halt. Lindberg ${ }^{49}$ noted that an initial degree of integration to achieve a particular benefit could require further integration in order to fully achieve that benefit. Nonetheless, the potential downside of partial integration is not limited to incomplete achievement of a benefit. Partial integration can prove actively damaging and can upset previous compacts between several competing factors in socially and economically important matters. Partial integration can take two forms. The first involves the integrating one policy area (e.g. monetary policy) but leaving another policy area (e.g. fiscal policy) which needs to be closely coordinated with the integrated policy area, in national hands. The second form involves integrating an area of policy but to an insufficiently supranational degree thus denying Union institutions to power to adapt such policy as necessary by allowing Member States to prevent changes in policy with relative ease (by requiring unanimity or

\footnotetext{
${ }^{48}$ See 'Profile: EU's Jean-Claude Juncker' BBC News, 15 July 2014 http://www.bbc.com/news/world-europe27679170 (last visited 19 February 2015).

${ }^{49}$ See above fn. 25.
} 
supermajorities for new legislation). In both of these scenarios, the first steps in the integration process were taken on the assumption that they would be followed by further steps (either the expansion of EU competence to other areas or the relaxation of law and policy making rules). If those further steps are not taken, the act of initial integration may impose costs that would otherwise not have been incurred. The first form these costs can take is that of 'policy incoherence' where steps towards integration bring about a situation where the various EU rules or a combination of EU and national rules, operate at cross purposes, undermining the ability of each to achieve the goals intended or where the rules and structures brought about by the degree of integration achieved to date produce otherwise avoidable negative outcomes for the Union and its Member States (such as lower growth and higher unemployment). The second form that costs can take is that of policy rigidity, where once EU law is in place it cannot be adapted as circumstances require due to the large supermajority needed to pass amending legislation. The spill-over mechanism can therefore end up being a net negative by creating extra disruption and suffering that can only be solved by further (politically impossible) integration.

The next section provides two examples of the first form of cost outlined above. It highlights two key features of the Union's current dilemma. First, it shows that the fact that integration process is now touching on areas that are more politically salient than before (both due to their political and symbolic importance and because of divergence between Member States as to appropriate policy options to pursue) means that previously successful integration mechanisms cannot achieve integration as they could in the past in relation to less salient matters. Second it shows that in each case, the level of integration achieved to date is inherently unstable and can be actively damaging. The first example relates to recent cases on EU citizenship such as Dano ${ }^{50}$ and Alimanovic ${ }^{51}$ where the Court of Justice, operating in the politically-charged area of welfare entitlements for EU citizens, felt unable to develop its caselaw on citizenship in the integrationist direction that characterised the rhetoric and substance of many of its previous decisions on EU citizenship. This has left the law in this area in a state that is apt to cause

\footnotetext{
${ }^{50}$ See above fn. 4.

${ }^{51}$ See above fn. 5 .
} 
significant incoherence in policy. The difficulties in the partially-integrated law on citizenship and welfare rights is mirrored in the second example, the Eurozone where Member States are unable to muster the political will to fulfil the need for integration of fiscal policy that the creation of a single currency created and are left with an actively damaging partially-integrated status quo.

\section{EU Citizenship and Social Welfare: Partial Integration Producing Policy Incoherence}

In Dano the Court of Justice was faced with a case that touched on the rights of EU citizens to access welfare payments. EU citizenship has been an area where the Court's jurisprudence has been characterised by a commitment to realisation of a more integrated future under which European political and civic identity increases in relative importance and distinctions between citizens of one's own State and those of other Member States are reduced. Judgements in this area have born the mark of the ECJ's unusual relationship to time. As noted above, the Court has repeatedly stated that Union citizenship was 'destined to be the fundamental status' ${ }^{22}$ of nationals of Member States, thus focusing its interpretative approach not solely on the current reality of EU citizenship but also on the future role that such citizenship must be developed to play in a more integrated future.

The Court has played a significant role in expanding the rights attached to EU citizenship, including welfare rights. However, previous rulings that expanded welfare rights of EU citizens affected relatively small numbers of people and did not generate much political backlash. ${ }^{53}$ That is no longer the case, levels of movement of workers between EU states have risen sharply since 2004, welfare budgets are under pressure due to the ongoing economic crisis and 'welfare tourism' is a hot political topic most notably in the United Kingdom's referendum on its continued membership of the EU.

In these circumstances, Ms. Dano's case, which involved a reference from a German court in which an economically inactive Romanian national, resident in Germany, challenged a refusal to

\footnotetext{
${ }^{52}$ Grzelcyck, Case C-184/99 [2001] E.C.R. I-6193.

${ }^{53}$ S. O'Leary 27 Yearbook of European Law [2009] 'Developing an Ever-Closer Union between the Peoples of Europe' 167 at 174-77, cited by D. Thym 'When Union Citizens Turn into Illegal Immigrants: The Dano Case' (2015) 40 European Law Review 249-262 at 260.
} 
grant her social welfare benefits, was particularly politically salient. Ms. Dano had argued that she had a right of residence in Germany as an EU citizen and that Directive 2004/38 ('the Directive') gave her the right to equal treatment with German nationals in relation to social welfare payments.

The Court ruled that as Ms. Dano was economically inactive, she had no right of residence under the Directive (the EU treaties also confer a right of residence but the Court assumed the Directive had correctly codified the rights of citizenship conferred by the Treaty). Previous judgments had identified the objective of the Directive as the facilitation of free movement rights and had seen any measure that limited such a right as an exception to the objective of the legislation that should be interpreted narrowly. However, in Dano the Court characterised preventing 'economically inactive EU citizens from using the host Member State's welfare system' as a key objective of the legislation rather than as an exception to those objectives. ${ }^{54}$ As Ms. Dano was not economically self-sufficient and had little chance of finding work, the Court concluded she did not have a right of residence in Germany under EU law and was not covered by EU law rights to equal treatment with German citizens in relation to social welfare payments. This more restrictive approach was confirmed by the Court in Alimanovic ${ }^{55}$ where the Grand Chamber, citing its decision in Dano, held that there was no right to equal treatment with Member State nationals in respect of social assistance payments for EU citizens whose right to remain in a Member State arose solely from their seeking of employment.

This along with the ruling in García-Nieto ${ }^{56}$ which followed the central holding in Dano and Alimanovic, tends to confirm Thym's suggestion that the decision in Dano represents are particularly significant turn away from the Court's attempts to drive forward the development of a more meaningful concept of EU citizenship. ${ }^{57}$ The ultimate objective of this drive was seen most notably in the Courts repeated statements in decisions since Grzelcyck that Union citizenship was 'destined to be the fundamental status' ${ }^{58}$ of nationals of Member States. Thym

\footnotetext{
${ }^{54}$ Above, n. 4, at [69].

${ }^{55}$ Alimanovic (C-67/14) ECLI:EU:C:2015:597

${ }^{56}$ García-Nieto (C-299/14) ECLI:EU:C:2016:114would

${ }^{57}$ N. 53 above.

${ }^{58}$ Grzelcyck, Case C-184/99 [2001] E.C.R. I-6193.
} 
rightly notes that the approach of the ECJ in this case can be seen as a decisive turn away from broader visions of European citizenship that are aspirational and which transcend 'the rationale of market integration'. The judges of the Court, he suggests, have 'abandoned attempts to participate in the legal construction of 'real' citizenship.' The case, he concludes, is a 'powerful reminder of the limits of transformative integration through law'. ${ }^{59}$

It is no coincidence that the reminder of these limitations came in the context of a politicallycharged case. The gleeful reaction of some national governments (most notably the Germany and the UK who receive high numbers of EU workers) ${ }^{60}$ shows the degree to which a win for Ms. Dano would have been extremely controversial. Peers wryly noted that the decision showed that European judges 'read the newspapers' ${ }^{61}$ Integration through law and functional integration were both designed to keep the integration process clear of politically-charged matters until a sufficient sense of European identity and the integration-created need for further integration made integration of sensitive areas possible. However, as Augenstein noted, ${ }^{62}$ that sense of identity has not developed as expected. Consequently, when faced with a highly-charged question such as welfare rights, the Court felt unable to adhere to its programmatic and ambitious visions of EU citizenship as it had done in other less controversial cases.

The decisions in Dano and Alimanovic could be seen as a case of disintegration rather than standing still. Peers saw Dano as involving 'a clear rejection, as compared to the prior case-law, of access to benefits by those who have never worked and who are not looking for work ${ }^{63}$ However, the caselaw on access to welfare benefits has always been rather unclear. ${ }^{64}$ In

\footnotetext{
${ }^{59}$ Thym, above $\mathrm{n} 53$ at $260-261$.

${ }^{60}$ See 'Court lets EU Nations Curb Immigrant Welfare' The New York Times, 12 November 2014, http://www.nytimes.com/2014/11/12/world/europe/european-union-welfare-benefits-to-immigrants.html (last visited 18 February 2015).

${ }^{61}$ See S. Peers 'Benefit Tourism by EU Citizens: the CJEU Just Says No' EU Law Analysis, 11 November 2014, http://eulawanalysis.blogspot.it/2014/11/benefit-tourism-by-eu-citizens-cjeu.html (last visited 18 February 2015).

${ }^{62}$ Above n. 32.

${ }^{63}$ Ibid.

${ }^{64}$ See for instance the tension between Case C-209/03 Bidar [2005] ECR I-2119, where the Court ruled a student could rely on Articles 18 and 21 TFEU to get access to a maintenance grant and Case C-158/07 Förster [2008] ECR I 8507, where the imposition of long integration periods for access to such grants was upheld. Even when the Court has upheld the right of equal access to benefits that seek to facilitate access to employment, it has been clear that
} 
addition, as Peers himself also notes, ${ }^{65}$ the key change in these cases is the increased deference on the part of the Court to the conditions on rights to residence and equal treatment in relation to security established by the Union's legislature in the Citizenship Directive. Thus, what the Court did was to grant less weight than before to Treaty-based programmatic notions of EU citizenship (such as the idea of the destiny of such citizenship seen in Grzelcyck) in its interpretation of the law relating to citizenship rights. The greatest change was not to what it has done in relation to the development of citizenship rights in the past but in the Court's perception of how those rights could be developed in the future; it was scaling back its programme to develop EU citizenship into the fundamental status of nationals of Member States. As will be discussed below, the Court did not wipe out the many existing citizenship rights that have previously been developed by the Court. Thus, the most significant change was not to the past of EU citizenship but to its future. By failing to question on Treaty grounds the limitations established by the legislature to citizenship rights in this area the Court has moved to a position where it regards such limitations no longer merely as temporary restrictions to be progressively removed as EU citizenship moves towards fulfilling its destiny to become the fundamental status of EU citizens.

The problem with this approach to EU citizenship is that it produces the kind of incoherence mentioned above where one set of EU norms operates at cross purposes from other EU or national norms. If such incoherence were a passing teething problem of EU citizenship that would be one thing, but if it is permanent, the costs will be much higher and will have significant consequences for the workability of EU citizenship and its interaction with other legal rules. For example, because the judgment did not reverse existing EU law rights to enter, move and re-enter states, it will be very difficult to actually expel 'illegal migrants' such as Ms. Dano. The Court has found that Ms. Dano has no right to residence under EU law and therefore no right to social assistance. The German authorities may therefore move to expel here. However, she retains under Directive 2004/38, a right to return to Germany at any stage and

this reasoning did not apply to 'social assistance' benefits access to which is limited by Article 24(2) of Directive 2004/38 (see Cases C-22 and 23/08 Vatsouris [2009] ECR I-4585.

${ }^{65}$ N. 61 above. 
cannot be refused entry on economic grounds. ${ }^{66}$ She and the German authorities are faced with a potential scenario of a never-ending round of expulsions and returns. The right to move freely and enter the territory of a Member State means that Ms. Dano cannot be stopped at the border and prevented from re-entering Germany. Procedural guarantees provided to EU citizens means that each expulsion is likely to be cumbersome, costly and time-consuming for the German authorities ${ }^{67}$ and if Ms. Dano gets to remain legally for 5 years at any stage she will then be able to enjoy full access to the welfare system. ${ }^{68}$ This is an inherently unstable situation that calls out for greater coherence.

Thus, we can see that in this case the spill-over mechanism can be a net negative by creating policy incoherence that can only be solved by further (possibly politically impossible) integration. The initial degree of integration provided by free movement and rights of residence creates (as the spill-over mechanism intends) the need for further integration. When this proves unattainable, incoherence results. Having developed a concept of citizenship in the light of a prediction in relation to the course of integration (i.e. that EU citizenship would become the fundamental status of member state nationals) the Court is left with a 'half-built house' when that prediction did not come true.

Of course, poorly-coordinated laws and policies are a phenomenon that occurs from time to time in all polities. The difference is that in the EU it is extremely difficult to take steps to ameliorate this situation. In theory, providing such coherence and re-establishing a more stable situation could potentially occur by granting greater access for EU citizens to national welfare systems. In the past the ECJ may have gambled that, as in the case free movement of goods, an adventurous, pro-integration interpretation of EU citizenship as including significant access to welfare rights would not generate an unmanageable level of backlash. However, welfare policy is now well outside the 'zone of indifference' within which Schmitter noted integration is

\footnotetext{
${ }^{66}$ Directive 2004/38 gives a right to EU citizens to admission to Member States who can produce a national ID card of a Member State and prevents refusal of entry on economic grounds (Articles 5 and 15, Directive (EC) 2004/38 of the European Parliament and of the Council of 29 April 2004 OJ L158.

${ }^{67}$ For confirmation that safeguards in relation to expulsion apply to EU citizens found not to have a right of residence under the Directive see Case C-50/06 Commission v Netherlands. [2007] E.C.R. I-4383.

${ }^{68}$ Directive 2004/38, Article 16(1) (n 49 above).
} 
easiest. ${ }^{69}$ The other integrationist option would be for such integration to occur via EU legislation. However, just as there is little public support for establishing the kind of panEuropean treasury and fiscal policy that could help resolve the Eurozone crisis, there is similarly low support for creating EU level welfare rights or an EU welfare system. ${ }^{70}$ In any event, the Court has now twice confirmed the holding in Dano, indicating that it does not feel capable of developing citizenship rights in this direction.

The alternative solution would be to restrict free movement rights to make it easier to prevent re-entry by those who have been expelled on the basis of a failure to fulfil the self-sufficiency condition set down by the directive. It is possible that the Dano decision could herald the beginning of a movement that brings about more radical restriction of EU citizenship rights but this would be very difficult to achieve under current EU structures. Restrictions beyond those accepted by the Court in Dano would require Treaty change which would be politically very difficult to achieve. In addition, Member States are rightly reluctant to unpick painfully worked out compromises as evidenced by the repeated statements on the part of the 27 states remaining in the EU that no deal could be reached with the UK following the Brexit referendum that permitted access to the Single Market without acceptance of free movement rights. $^{71}$ Every state has aspects of free movement or other legal principles with which it is unhappy so attempts to roll back free movement rights would risk a wider unravelling of the EU project. As the United Kingdom is discovering following its referendum, curtailing EU law rights is extremely difficult as so many economic and social arrangements have been made on the basis of such rights. Similarly, for remaining EU members, substantial restriction of free movement rights would be economically and socially disruptive given that millions of Europeans, from German retirees to Polish plumbers have moved to live and work in other EU states or have set up other arrangements in reliance on existing free movement rights. Of course, the

\footnotetext{
${ }^{69}$ Discussed in Rosamond (n 25 above) at 64.

${ }^{70}$ A notable proposition in this regard was that of Schmitter who argued for a 'Euro Stipendium', summarised by Van Middelaar 'a monthly allowance for all citizens of the Union whose income is less than a third of the average' L. Van Middelaar The Passage to Europe (translated by L Waters) (Yale University Press, 2013) at 262.

${ }^{71}$ See, for example 'EU “Crystal Clear" that Single Market Access Means Accepting Freedom of Movement' The Daily Mail, 30 June 2016 (www.dailymail.co.uk/wires/pa/article-3665103/Cameron-Makes-exit-EU-talksBrexit.html).
} 
unpredictable nature of politics means nothing can be ruled out. Political pressure may be such that Member States decide to bear the cost of the disruption caused by scaling back citizenship rights drastically. The point of this article is not that such an eventuality would never occur but rather to point out that 'standing still' (neither regressing nor progressing) is not a viable option. In any event, the difficulty of securing even legislative change in this area is shown by the fact that even when the Court of Justice has rendered decisions such as that in Metock ${ }^{72}$ which expanded free movement rights in ways opposed by a clear majority of Member States, legislative reversal of the judgment has not been possible.

\section{The Eurozone: Partial Integration Producing Destructive Policy Outcomes}

The dangers to the policy coherence that results when political salience serves to prevent the integration process continuing as the spill-over process requires are not restricted to the specific legal issues raised in Dano. They are representative of the broader challenges facing the Union both in relation to the Eurozone and to the Union's political system more generally.

There can be little doubt that the future of the Eurozone is a highly-salient issue or that this salience is a major impediment to the realisation of the further integration that most observers and most Member State governments believe is necessary to resolve the crisis. As already noted, Jean-Claude Juncker famously said, Member State governments know exactly what they needed to do to resolve the Euro crisis but do not know how to get re-elected once they had done this. $^{73}$

The travails of the Eurozone are also a clear indicator of the fact that the potential downside of partial integration is not limited to incomplete achievement of a benefit. They are, in fact the perfect demonstration of how partial integration can cause policy incoherence and can prove actively damaging as well as upsetting previous compacts between several competing factors in socially and economically important matters. In depth economic analysis is beyond the scope of

\footnotetext{
${ }^{72}$ See for example the failure to reverse the ruling in Metock (Case C-127/08. [2008] E.C.R.I-6241) although a large number of Member States opposed this ruling.

${ }^{73}$ See 'Profile: EU's Jean-Claude Juncker' BBC News, 15 July 2014 http://www.bbc.com/news/world-europe$\underline{27679170}$ (last visited 19 February 2015).
} 
this article and the competence of the author, ${ }^{74}$ but one does not need to be a professional economist to understand and recognise that unifying monetary policy in the Eurozone deprives Member States of the ability to tailor monetary policy to the specific needs of their national economy and has accordingly upset the balance between monetary and fiscal policy in national economic policy making. It has meant that, because states could not use monetary policy to regain lost competitiveness they have had to rely on painful internal devaluation at the cost of enormous suffering.

Furthermore, given the economic divergence between Eurozone states, some states will inevitably be stuck with an interest rate that is too high for them but too low for some of their partners. As Gerner-Beuerle et al. point out, in federal systems, fiscal policies play an important role in facilitating the adjustment of the different regions to asymmetric shocks'. ${ }^{75}$ In the United States, for example, taxing and spending by the federal government helps to compensate for economic divergence between states. A booming state will pay more in tax some of which will be transferred in the form of welfare payments to a state that is in economic difficulties. This helps to compensate for the rigidity caused by the setting of a single monetary policy. ${ }^{76}$ This does not occur in the EU as the integration achieved so far has been partial, covering monetary policy only.

The establishment of the single currency therefore created, in classic spill-over fashion, the need for further integration of other areas such as fiscal policy. This kind of integration could have been facilitated in a number of ways. A sense of European level political identity and loyalty could have grown that built support for transfer of powers over fiscal policy to EU level. Alternatively, electorates, while still lacking strong European identities, may have been sufficiently unconcerned by the issue of fiscal competence to have adopted a permissive approach to measures transferring such competences to the Union. Neither of these scenarios

\footnotetext{
${ }^{74}$ See, for example, P. De Grauwe Economics of Monetary Union (Oxford and New York, Oxford University Press, 9th ed. 2012).

${ }^{75}$ C. Gerner-Beuerle, E. Küçük and E. Schuster, 'Law Meets Economics in the German Federal Constitutional Court: Outright Monetary Transactions on Trial' German Law Journal 15 (2): 281-320.

${ }^{76}$ See R. McCrea 'The EU Should Put its Money Where its Mouth Is: the Need for Fiscal Competence at EU Level' The Irish Times, 13 January 2004 which argued that the Euro was unsustainable without integrated fiscal policy.
} 
applied. The sense of European identity has not developed to the extent that voters in creditor countries are willing to contemplate a transfer union where EU fiscal competence forms the basis for transfer payments from states with economic growth to those in recession. In addition, the issue of transfer of fiscal competence to the EU has proved to be highly salient in political terms, indeed, the unhappy experience of the Euro has hardened opposition to further economic integration (notwithstanding that such integration may be a partial solution to the problems caused by the Euro).

Furthermore, in contrast to the relative consensus on socio-economic policy that applied between Member States in the early decades of the integration process, there is a high degree of divergence between current Member States both in terms of economic development and in terms of perceptions of the correct social and economic policies to pursue (the view of the ideal solution to the crisis in Athens and Paris is very different from the view in Berlin and Helsinki). In these circumstances, it is not surprising that voters have proved highly resistant to moves to transfer fiscal competence to the Union, there is no agreement either on whether to transfer such powers or on what policy goals to pursue with such powers should they be transferred.

Intergovernmental Co-Operation: A Feasible Third Way?

It would be unfair to describe the Eurozone states as having entirely stood still in the face of the crisis. Faced with pressure from the spill-over process to integrate further to mitigate the economic problems caused by the design of the Euro and with political pressure against moves to confer fiscal or other economic competences on the EU, Member States have been forced to come up with forms of integration that depart from approaches that involved conferral of substantial power on EU institutions.

The period since 2008 has seen significant efforts to develop intergovernmental structures to help the Eurozone to cope with the crisis without conferring significant additional competence on EU institutions. Faced with Eurozone states in severe financial difficulty and Treaty prohibitions on the provision of loans or bail-outs by the $\mathrm{ECB}^{77}$ the Member States established

\footnotetext{
${ }^{77}$ Articles 123 and 125 TFEU.
} 
intergovernmental bodies such as the European Financial Stability Facility ${ }^{78}$ and later the the European Stability Mechanism. ${ }^{79}$ These bodies were intended to provide loans to Member States in financial difficulty. The degree to which established EU structures were unable to cope with the challenge is underlined by the fact that such bodies were established on the basis of intergovernmental agreements between Member States outside of the framework of the EU law.

Integration in the area of economic policy has focused on strengthening procedures involving surveillance and coordination of the economic policies of Member States with relatively few substantive powers being conferred on EU institutions. The 'European Semester' provides a mechanism for coordination of Member State economic and budgetary policies. The European Council establishes guidelines for national policies against which national plans and policies are judged. While it is true that the European Commission may issue 'Country-Specific Recommendations' on a range of economic policies these recommendations are discussed and approved by the ECOFIN Council of EU finance ministers. ${ }^{80}$ The Union has also established what has become known as the 'Six Pack'. This is a set of six changes to the Pact for Stability and Growth covering state fiscal policies and what are called 'macro-economic imbalances'. ${ }^{81}$ Though mainly intergovernmental, these measures do have some teeth. Under these procedures Member States at risk of 'macro-economic imbalances' are identified and are given recommendations by the European Council on the basis of proposals by the Commission. Financial sanctions for non-compliance can be imposed on Member States that fail to make the necessary adjustments to their economic policies. Eurozone states have also adopted a 'Fiscal Compact' which requires national parliaments to avoid government deficits of over $0.5 \%$ of GDP. ${ }^{82}$ This agreement also envisages possible financial sanctions for non-compliance.

\footnotetext{
${ }^{78}$ See: Brussels, Council of the European Union, 10 May 2010, 9596/10 (Presse 108).

${ }^{79}$ Treaty Establishing the European Stability Mechanism (2012).

${ }^{80}$ See 'The European Semester' The European Commission, available at: http://ec.europa.eu/economy finance/economic governance/the european semester/index en.htm (accessed 20 July 2016).

${ }^{81}$ See the Sixpack (package of 5 regulations and one directive) OJ L 306, 23 November 2011.

${ }^{82}$ Treaty on Stability, Coordination and Governance in the Economic and Monetary Union (2012).
} 
These measures are notable for the predominance of intergovernmental action. The EFSF and ESM were set up by intergovernmental treaty. Surveillance powers have been increased, sometimes with penalties for non-compliance, but the key decisions as to what aims are to be selected and what punishments are to be issued are made by the Member States. The European Parliament has no significant role and the European Commission is largely reduced to carrying out the instructions of the Member States with little power to take binding decisions independently.

\section{Some Recourse to Familiar Methods}

Of course, the picture is rather complicated and some of the steps taken do have recognisable traces of forms of integration that achieved success in the past. The Member States have agreed to confer greater powers of supervision of the banking system on the ECB (though tellingly, they have as yet been unable to agree upon a full banking union that would include a common deposit insurance fund or single resolution mechanism for cases when banks fail).

Similarly, just as the Court of Justice rescued the EEC from 'euro sclerosis' in the 1970s through its audacious interpretation of the Treaty articles on free movement, the Court has played a key role in the Eurozone crisis. Most notably, it has adopted a lenient approach to policing the limits of the powers of the European Central Bank. Despite the fact that the ECB is prohibited from offering 'overdraft facilities' to Member State governments under the Treaty, in 2012 the Bank adopted the 'Outright Monetary Transactions' policy ${ }^{83}$ under which it undertook to buy unlimited quantities of government bonds in order to ensure that the Bank's decisions on interest rates were properly transmitted to financial markets (subject to compliance by Member State governments with the conditions imposed by any ESM or IMF backed programmes (such as the 'Memoranda of Understanding' agreed with Greece, Ireland and Portugal as part of their post-crash bail outs). Adopting the widest possible view of the powers of the ECB, the Court of Justice held that this programme fell within the boundaries of

\footnotetext{
83 'Technical features of Outright Monetary Transactions' European Central Bank Press Release, 6 September 2012.
} 
monetary policy, did not violate the ban on deficit financing and was accordingly not ultra vires. $^{84}$

Similarly, in the Pringle case in relation to the establishment of the ESM, the Court of Justice rejected a challenge alleging that the ESM amounted to interference with the EU's exclusive competence in relation to monetary policy and undermined the no bail-out, no loan requirements of Articles 123 and 125 TFEU.

The travails of the Eurozone are a powerful indicator of the degree to which, integration in one area can produce the need for integration in other areas as well as the problems that arise when the political salience of the area in question prevents such further integration from taking place. The economic and social difficulties caused by the 'half-built house' of the Eurozone mean that standing still and maintaining a single currency without any integration of fiscal policy is not an option. The intensity of opposition to transferring fiscal competence to EU institutions means that such integration as has taken place has been notably governmental. The Court of Justice has assisted by providing generous interpretations of the scope of the powers of the ECB. However it would be politically impossible for the Court to use its judicial powers to break the political deadlock and advance fiscal integration in the same revolutionary way it did in relation to free movement rights in Cassis de Dijon in the 1970s.

\section{A Feasible Solution?}

There must be significant doubt as to whether the forms of intergovernmental cooperation provide a sustainable basis for the Eurozone or successfully address the negative outcomes in terms of lack of coordination between fiscal and monetary policies that the creation of the Eurozone has brought about. The intergovernmental measures taken have certainly introduced greater supervision and control of national fiscal and economic policies but they fall well short of the kind of fiscal transfer union needed to allow the Eurozone to operate in the same way as successful monetary unions such as the USA where fiscal transfers from the centre help to even out the economic cycle within a monetary union where the interest rate may be too low for booming regions and too high for those in recession. Indeed, it seems that those kind of

\footnotetext{
${ }^{84}$ Gauweiler (C-67/14) ECLI:EU:C:2015:400
} 
measures have been renounced even as goals by EU institutions and Eurozone states. Although the scale of changes necessary to make the Eurozone work has not changed in the past few years, there has been a notable shrinkage during that period in what leading pro-integration figures believe is even worth aiming to achieve. In 2012 the 'Four Presidents' Report' ${ }^{85}$ was issued by the presidents of the European Council, European Commission, the ECB and the Eurogroup (the group of finance ministers of Eurozone states). The report argued for 'genuine economic and monetary union' including a 'banking union, significant integration of budgetary policies including a possible additional budgetary capacity at Eurozone level and a common debt instrument (a limited form of Eurobond called Eurobills), and a strengthening of democratic legitimation and accountability - potentially brining about at least a degree of political union. ${ }^{86}$ Yet, as Begg notes, 'only the banking union dimension made much progress' and even in that area Member States have shied away from measures such as a single resolution fund and common deposit insurance mechanisms which might involve significant transfers from one state to another. ${ }^{87}$

There is no reason to think that such measures had become less necessary in the ensuing three years yet when the Five Presidents (the original four having been joined by the President of the European Parliament) released a further report ${ }^{88}$ in 2015 the reduction in the ambition of the measures proposed was striking. As Begg noted the more contentious components have been dropped or toned-down in scope. There is no longer any mention of new fiscal capacities nor of debt mutualisation. Instead there is a more vague call to create a 'fiscal stabilisation function', the details of which will be worked out by an expert group to be set up in due course. Principles for fiscal stabilisation include avoiding a system that will result in permanent cross-border

\footnotetext{
${ }^{85}$ Council of the European Union, 'Towards a Genuine Economic and Monetary Union' 5 December 2012.

${ }^{86}$ See I Begg 'What does the Five Presidents' Report Mean for the Future of the Euro?'EUROPP Blog http://blogs.Ise.ac.uk/europpblog/2015/06/23/what-does-the-five-presidents-report-mean-for-the-future-of-theeuro/?utm source=feedburner\&utm medium=email\&utm campaign=Feed\%3A+Europp+\%28EUROPP++European+Politics+and+Policy+at+LSE\%29 (accessed 19 July 2016).

${ }^{87}$ Ibid.

${ }^{88}$ European Commission 'Completing Europe's Economic and Monetary Union' 22 June 2015 available at: https://ec.europa.eu/priorities/sites/beta-political/files/5-presidents-report en.pdf (accessed 19 July 2016).
} 
transfers - plainly intended to allay the concerns of the creditor countries - as well as ensuring compliance with fiscal rules. ${ }^{89}$

The extent of political resistance to further economic integration is therefore such that the Presidents have ceased even to aim for measures which, three years previously they thought were vital to the survival of the Euro. Therefore, while not quite standing still, the Union has been unable to move forward to the degree necessary to safeguard the Euro or eliminate the costs that an imbalanced monetary union is imposing on Member States. The Union is therefore stuck between the powerful need to integrate fiscal policy to enable to Eurozone economy to function properly and the equally powerful political resistance to the integratiave measures needed to carry this out.

The extensive intergovernmental cooperation achieved is testament to the political determination of the Member States to save the Euro. The audacious actions of the ECB upheld by equally audacious interpretations on the part of the Court of Justice speak to a similar determination on the part of EU institutions. While a combination of Member State political will and EU institutional audaciousness has succeeded, for the time being, in staving off the existential threat to the Euro, these measures have primarily aimed and functioned so as to preserve the existence of the single currency. They have not been the harbingers of a new phase of integration that harnesses the spill-over effect to allow for further integration. They can be seen more as measures that aim to 'stand still' and preserve monetary union rather than as evidence of successful operation of the spill-over mechanism. None of the measures comes anywhere close to 'spilling over' into the establishment a fiscal union. There has been no expansion of the EU budget to allow it to fund counter-cyclical measures in depressed areas, no establishment of an EU finance ministry and no mutualisation of debts. All measures to date have aimed at maintaining the already-integrated nature of monetary policy (by saving the single currency) rather than allowing integrated monetary policy to spill over into integrated fiscal policy. If political opposition amongst Member State electorates were not a factor or if political identification with Europe had grown more than it has, perhaps integrated monetary

\footnotetext{
${ }^{89}$ See Begg above n. 86.
} 
policy would have, with a few inevitable bumps in the process, spilled over into integrated fiscal policy but this has not happened. Electorates are sufficiently opposed and sufficiently motivated in their opposition to ensure that such spill over is politically impossible. We remain stuck with what De Grauwe has characterised as 'incomplete monetary union' with mechanisms that are, in his view, too small to provide an effective means of preventing the development of crises of confidence in Member States and are not adequate to allow the Union to respond to economic shocks. ${ }^{90}$

Therefore, in relation to the Eurozone, the spill-over mechanism has created the need for a form of integration that is impossible to achieve politically. The failure to achieve that integration results in highly destructive policy incoherence with unduly long recessions and high unemployment in some regions and a general climate of recrimination and resentment. As in the case of free movement rights, moving forward or backwards would be extremely difficult. There is no political appetite for either of the measures necessary to resolve the incoherence. Very few wish to cause the huge disruption or to incur the vast costs that dissolving the currency union would involve. Neither will voters countenance the degree of fiscal union necessary to make the Euro workable. The solution cannot come from the integrative mechanisms previously relied upon. The permissive consensus is over. Electorates are highly engaged in their opposition to fiscal integration, the number of Member States is much higher than in the 1970s and 1908s and there is no consensus as to what economic policy should be even if the EU did manage to gain some authority over it. The Eurozone is as Tim Parkes [EU says, half way across a stream 'unable to complete the transition it has set itself, rather than fording the stream it is sinking in the mud'. ${ }^{91}$ Remaning mid-stream, as he rightly notes, is not a solution.

\section{Partial Integration and Legislative Rigidity}

If, as I argued, the Eurozone's problems show that the spill-over mechanism, aided by creative judicial interpretations can no longer deliver integration when the areas to be integrated become strongly salient politically in the Member States, we are dependent on the political

\footnotetext{
${ }^{90}$ N. 74 above at 17 and 124.

${ }^{91}$ T Parks "Why the EU Had it Coming' The New York Times, 10 July 2016.
} 
system of the Union to use its powers to deliver solutions to the policy incoherence brought about by partial integration. Yet, as I have already noted above that in relation citizenship and welfare rights, there is little prospect that any measure capable of resolving the incoherence highlighted by the Dano decision is unlikely to gain the support needed to make it through the legislative system of the Union. Put simply, the Union's law making structures are not sufficiently flexible to allow EU law to be adapted as necessary. Scharpf has written of the 'joint decision trap' noting that where decisions require a large majority or unanimity 'the default provision will always be the status quo' ${ }^{92}$ even when this is not anyone's desired outcome. This is a scenario that is particularly likely to arise in the EU.

The Union's legislative system is one that can be said to be 'partially integrated' even in relation to areas where it enjoys full competence. In many multilevel polities the central government has full authority to legislate over the areas ceded by the sub-units to common control. ${ }^{93}$ This is not the case in the EU where the rules for enacting or amending legislation provide significant scope for Member States to prevent changes to laws. Many key areas of policy remain subject to unanimity and the institutions established to deal with the Eurozone crisis all require supermajorities for significant decisions. Any treaty change to bring about more fundamental change to alleviate the Eurozone crisis will require unanimous agreement of Member States. Much has been written about the negative effect of political gridlock in the United States. ${ }^{94}$ The American legislative system has such a proliferation of veto players that amending laws is exceedingly difficult and it is therefore hard for law to be adapted as society's knowledge and needs change. The EU legislative system is even more rigid. European law now covers important areas such as employment law, elements of environmental policy and budgetary matters all of which interact with changing social and economic realities. However, it will be extraordinarily difficult to change these laws even if they are revealed to be damaging to the economic or

\footnotetext{
${ }^{92}$ Discussed in Rosamond, note 25 above, at 61.

${ }^{93}$ In US, even the rule requiring 60 votes to close debate on a proposal in the Senate is actually a rule of procedure of the Senate itself rather than a constraint on the ability of the federal government to legislate by simple majority over areas it controls.

${ }^{94}$ See for example D. W. Brady, Revolving Gridlock: Politics and Policy from Jimmy Carter to George W Bush $\left(2^{\text {nd }}\right.$ ed.) (Westview Press, 2006) which argues that gridlock is built into the American legislative and policy-making system.
} 
social interests of the Union or most Member States. Indeed, in many areas, such as free movement, change can come only if all Member States support it. What prospect would legislative reforms have in the United States have if any changes to areas such as employment law or environmental standards had to be approved by the Governors of all 50 states? Given the rise of populist parties in many Member States, the prospect of a single state paralysing decision-making cannot be discounted.

It must be acknowledged that, although Treaty change remains subject to unanimity, in relation to legislation passed under the Treaties, there has been a steady erosion of national vetoes. The use of Qualified Majority Voting (QMV) has been expanded to cover a wider range of areas with each revision of the Treaties. The significance of this should not be minimised. The willingness of Member States and their peoples to be bound by the decisions of other states with which they may disagree is remarkable. Impressive though this may be, it does not mean that the EU political system is capable of dealing with the challenges posed by partial integration of politically salient areas.

Even where a matter is covered by QMV, there is often reluctance in the Council of Ministers to depart with the culture of consensus that has built up over decades and to pass legislation that some Member States strongly disagree with. Even if this is overcome and the Council seeks to adopt legislation by QMV, the majority needed is very high (55\% of the states representing $65 \%$ of the population of the Union). This is the kind of level of support more akin to the kind of supermajorities needed to amend constitutions in many states. ${ }^{95}$ Indeed, Tridimas notes how the difficulties of securing support in the legislative system has made the Union rather dependent on the innovative approach to interpretation of the ECJ. He argues that political deadlock between Member States has often led to the production of 'fudged' or unclear legislative texts, encouraging (and perhaps depending on the Court, to resolve this lack of clarity through adventurous interpretations. ${ }^{96}$ The weakness of the EU's political institutions

\footnotetext{
${ }^{95}$ This is a key difference from the German system where state governments in the Bundesrat do have the ability to block some actions of the federal government but where a majority rather than a super-majority is needed to put a measure through the upper house.

${ }^{96}$ T. Tridimas 'The Court of Justice and Judicial Activism' 21 European Law Review 199 [1996] at 205.
} 
and their need to grant Member States wide scope to block legislative measures has meant that historically, the EU's law-changing abilities were like the senses of a blind person whose hearing developed extra capabilities in order to compensate for the lack of vision. The European judiciary, like the blind person's hearing, has, taken on a role in the development of the law that was beyond that normally given to courts. However, the enhanced hearing ability of a blind person does not fully compensate for the lack of vision and similarly, adventurous interpretation by the Courts is not an adequate substitute for a functioning, flexible political system. The introduction of QMV gave the EU political institutions more 'sight' than before but still much less than the political institutions of a normal polity. If the Court is no longer willing to play the large (and democratically problematic) role in law-making and promoting further integration that it has historically played, the EU maybe left relying on political institutions that are still institutionally incapable of bearing this burden. ${ }^{97}$

The EU's political system must operate by supermajority. Unlike a national parliament whose electorate is bound by a dense national identity that allows a national government to take a decision that may enrich one region and impoverish another without the latter region questioning its authority. Because of the failure of a strong European identity to emerge, the different regions of the EU remain the primary focus of political loyalty. Accordingly, EU political institutions do not have the authority to create winners and losers in the way a national government can. Its system must therefore give scope to Member States to block measures which they feel harm their key interests thus, the EU's political system requires supermajorities for many key decisions. As it operates by supermajority (and often unanimity) this system requires an extraordinary degree of political consensus as to the type of policies that ought to be pursued. As noted above, the level of political agreement on economic matters that existed in early the early decades of the integration process no longer applies. Indeed, the recent rise of populist parties who challenge the centrist Christian and Social Democratic

\footnotetext{
${ }^{97}$ Here a parallel can be drawn to the economic governance of the Eurozone where the absence of adequate fiscal powers at EU level has meant monetary policy has been required to take on a disproportionately large role in dealing with the crisis.
} 
parties that have long dominated politics in most EU states shows that the degree of political consensus is falling not rising.

Therefore, it is not merely the substantive law of the Union that requires further integration to function adequately. The EU's law-making system itself needs to be significantly more supranational than it currently is if the Union is to prove viable and effective as policymaker in the long term. No legal system can hope to react effectively to changing economic circumstances if all of its law is entrenched in a manner similar to constitutional entrenchment at national level making and is therefore extremely difficult to amend. As noted above, Burke's observation 'A State without the means of some change is without the means of its conservation' $^{98}$ may well apply to the EU. Member States do not trust each other sufficiently and European citizens are too attached to their nation states to empower European institutions with the necessary legislative rules that would allow EU law to be easily amended. Easy amendment would make it too easy to expand EU powers or for a majority in EU institutions to pass laws inimical to the interests of particular states. National parliaments which benefit (in most Member States) from strong national loyalties, have the authority to take decisions that benefit one region and disfavour another. EU institutions' voting rules reflect the fact that they simply do not have the kind of cultural or political authority to pass or amend laws in ways that make winners of some states and losers of others without losing the allegiance of the latter. On the other hand, in the long term, we cannot have a system where vast areas of law, much of which deals with changing and dynamic areas such as employment law, are effectively unamendable. Current law-making structures are workable only as transitional institutions which pave the way for a more integrated Union where the national vetoes (and even the super majorities that apply to QMV) that make the current system so rigid, are much less common and it is far from clear that such a set-up is an attainable prospect.

\section{Conclusion}

\footnotetext{
${ }^{98}$ E Burke, Reflections on the Revolution in France (Oxford World Classics, 1993) (L G Mitchell ed.).
} 
Functional integration, the spill-over process and integration through law have helped EU to achieve a very impressive degree of European integration. However, they have also themselves produced the need for further integration that may be politically impossible. As the examples of citizenship rights, the Eurozone and the Union's law making structures show, this unmet need may prove very damaging. The EU now finds itself in something of a catch 22 situation. The electorate in most Member States want neither disintegration nor significantly intensified integration but standing still and maintaining current levels of integration is causing incoherence in policy and is actively destructive in some areas.

Although it has been criticised, ${ }^{99}$ the idea that that European integration is like a bicycle (that it has to be moving forward or it will fall over) appears to be partly correct. I do not mean correct in the sense in which it was used by some of its proponents such as Jacques Delors, as a justification for further integration but rather in that it described the potentially destructive consequences of partial integration. 'Ever closer union' was not just a phrase, as Mancini suggested, it is deep in the DNA of the EU and may be an existential condition for the effectiveness and viability of the Union and its. The methods of integration chosen by those who founded the EEC mean that it is very difficult to call a halt to the integration process but the drop in political support for further integration raises acute dilemmas for the Union by creating demand for just such a stop.

The use of functional integration and integration through law represented ways to get around the fact that integration of politically-salient and emotionally charged areas had insufficient public support. In conjunction with the integrative role played by the law (especially the Court of Justice) a large degree of integration was achieved. However, this could only be a temporary expedient. Spill-over and ever closer union meant that at some stage the integration process would begin to touch on highly salient areas. The sustainability of the integration process at this stage was always going to depend on 'loyalty transference' i.e. the emergence of the degree of European identity and public support for integration that was initially lacking. Whether or not one favours taking further steps in the integration process, one cannot get away from the

\footnotetext{
${ }^{99}$ See for example, T. Garton-Ash ‘Europe's Endangered Liberal Order’ Foreign Affairs (1998) Vol. 72 51-65, 62.
} 
reality that many of the steps now completed were made in the assumption that they would be followed by additional steps.

The collapse of the permissive consensus and progressively more difficult ratification of each successive treaty have shown that this support has not developed. Furthermore, though integration was a success in many areas, in some key areas, such as the Euro, the unhappy experience of integration on the part of many Member States has actively undermined support for further integrative steps. There is low support for a break-up of the Union but there is equally low support for significantly intensified integration. One possible response is to muddle through with various incremental measures that increase integration slowly and thus avoid political backlash. It is not clear that this is feasible long-term solution. As political salience of integrated areas has increased so has political and legal resistance to creeping integration. The 2011 EU Act in the UK required a referendum for any new transfer of power to the Union, no matter how slight ${ }^{100}$ and the aim of the British government to remove the commitment to ever closer union from the treaties has relatively high public support in many Member States ${ }^{101}$ Indeed, neither the guarantees of the EU Act nor the recognition by other Member States that the UK was not committed to ever closer union was sufficient to avoid a majority vote to leave the Union in the UK's 2016 referendum. These issues are not restricted to problematic Member States such as the UK which was never fully on board with the political integration element of European integration. On the legal front, the German Constitutional Court has been consistently warning that the Union is reaching the outer limits of the incremental integration which it can tolerate. ${ }^{102}$ While it is true that, particularly in relation to the Eurozone, Member States have been experimenting with more inter-governmental forms of integration. However, the degree of integration achieved by these methods is insufficient to remedy the policy problems being caused by the Eurozone's design. In addition, intergovernmental structures are even more prone to paralysis than the already, highly rigid law-making structures that

\footnotetext{
${ }^{100}$ European Union Act c 12, 2011, section 4.

${ }^{101}$ See R. Ruparel 'Appeal of Ending Ever Closer Union Stretches Well Beyond the UK' Open Europe, 13 August 2015 http://openeurope.org.uk/blog/appeal-of-ending-ever-closer-union-stretches-well-beyond-the-uk/ (last visited 25 September 2015).

${ }^{102}$ See 2 BvE/08, Judgment of 30 June 2009.
} 
characterise the European Union so provide no solution to problem of the EU's rigidity and inability to effect change.

If further integration is impossible to achieve then reversing the integration process is another option. It is one that would be enormously costly and involve abandonment of the idea of evercloser union that, as the unusual relationship of the Court of Justice's jurisprudence to times shows, has been at the core of the integration project to date. Were it to occur it would represent confirmation of the central thesis of this article, namely that standing still is not a viable option and either further integration or disintegration is required.

Functional integration and integration through law were means by which it was hoped to create facts on the ground that would eventually encourage. As Hoffmann pointed out as far back as $1966,{ }^{103}$ there was a fundamental decision to be taken as to whether the aim of European integration was creation of a further super-state or to go beyond the state as a paradigm for government. The hope was, that decision on this and on the fuller integration of key areas could be put off until the day when integration itself had convinced the peoples of Europe that intensive integration was what they desired. It seems increasingly likely that that day will never come.

Writing in 1958 at the height of the brutal conflict over Algerian independence, the French philosopher Raymond Aron pointed out that, as Tony Judt ably summarised, 'France lacked both the will and the means either to impose French rule on the Arabs or to give the Arabs an equal place in France. If the French stayed the situation would only deteriorate and they would inevitably leave at some later date -but under worse conditions and with a more embittered legacy [...] However impossible the choice appeared, it was nonetheless very simple. France must go'.

The core of Aron's warning was that sometimes we face stark dilemmas that can only be resolved by decisive choices. The unsustainable nature of the status quo of 1958 Algeria and

\footnotetext{
${ }^{103}$ S. Hoffmann 'Obstinate or Obsolete: The Fate of the Nation-State and the Case of Western Europe' Daedalus Vol. 95(3) Summer 1966, p. 157.
} 
the fruitlessness of the French pursuit of an option less radical than recognising Algerian independence, may hold lessons for today's EU leaders. There are circumstances when maintaining the status quo is unsustainable and when decisive actions are the only feasible option. While it was clear in 1958 that France lacked the will to take any of the decisive steps needed to maintain its rule in Algeria, it is not entirely clear that EU Member States lack the will to move the integration process forward to the degree necessary to make EU law-making sufficiently flexible and to resolve the negative outcomes and policy incoherence being caused by partial integration in areas such as the Eurozone and EU citizenship. Eurozone states have taken significant steps to coordinate economic policies and to establish bodies that can provide emergency loans to states in difficulty. However, these steps fall some way short of the kind of decisive measures needed to cure the Eurozone's ills. In addition, there appears to be little or no appetite for fundamental the reconsideration of EU voting rules needed to make the EU a sufficiently flexible policymaker. Member States seem determined to stick with a version of the status quo, taking piecemeal measures that do not satisfactorily address the fundamental issues facing them. Aron's insight was to see that for France, there was no way to avoid a decisive choice and that playing for time may only increase the cost of the inevitable difficult choice to be made. The EU's status quo is not sustainable. Attempting to live in denial of that fact will only make the inevitably hard choices to be made more costly. 